\title{
The Driving Factors of China's Housing Prices Pre- and after 2012
}

\author{
Haishan Li ${ }^{1 *}$, Ting Pan², Qianqian Tang², Zhengxun Tan ${ }^{2 *}$ \\ ${ }^{1}$ School of Shipping Economics and Trade, Guangzhou Maritime University, Guangzhou, China \\ ${ }^{2}$ Department of Finance, Business School, Hunan Normal University, Changsha, China \\ Email: ${ }^{* 13450400603 @ 126 . c o m, ~}{ }^{*}$ tzxun1810@163.com
}

How to cite this paper: Li, H.S., Pan, T., Tang, Q.Q. and Tan, Z.X. (2021) The Driving Factors of China's Housing Prices Pre- and after 2012. Journal of Mathematical Finance, 11, 255-266.

https://doi.org/10.4236/jmf.2021.112015

Received: February 24, 2021

Accepted: May 14, 2021

Published: May 17, 2021

Copyright ( 2021 by author(s) and Scientific Research Publishing Inc. This work is licensed under the Creative Commons Attribution International License (CC BY 4.0).

http://creativecommons.org/licenses/by/4.0/

\begin{abstract}
While GDP and the money supply (M2), the two key demand fundamentals of China's housing prices, shifted gears and decelerated after 2012, China's housing prices maintained high growth rates, specifically during 2015-2018. To explain the puzzling phenomenon, we use the TVP-VAR model to compare the time-varying features of the factors driving up the housing prices. Our results depict the interesting finding that before 2012, macro-fundamental factors such as M2 and per capita GDP were the key drivers of housing prices. But after 2012, shadow banking had gained explanatory power alongside M2 and per capita GDP.
\end{abstract}

\section{Keywords}

Housing Price, Shadow Banking, TVP-VAR Model

\section{Introduction}

The issue of housing prices has always been a topic of great concern. Scholars at home and abroad have tried to explain the growth and fluctuation of housing prices from various angles, including the supply-side [1] and the demand-side [2]. In China, the issue of housing prices is of particular concern because the country has maintained an astonishing constant rise in housing prices for more than three decades ever since the 1980's reform of the housing supply mechanism. Scholars have analyzed the factors of the rising housing prices one after another and put forward various explanations. Income and interest rates [3], the government's ability to control land supply [4] and among other factors are found to be important elements that influencing different levels of housing prices in China.

Most studies of housing price determination confirmed the explaining power 
of GDP and money supply as the most essential determinants. For example, Tan et al. [5] found that the fundamental value of housing prices is determined by macroeconomic factors of GDP and money supply. Li and Chiang [6] discovered an equilibrium relationship between housing prices and GDP. Oikarinen et al. [7] concluded that GDP growth is the crucial factor of house prices, and particularly Aizenman et al. [8] suggested that house price appreciations are positively associated with economic growth in 19 countries. Evidence also showed significant influence of monetary policy on house prices in various countries, including Sweden [9], US [10], South Africa [11] and Kazakhstan [12]. Housing price booms are typically proceeded by a period of easing monetary policy [13]. Looser lending condition in the sub-prime mortgage market explained the run up in house price in the US between 1998 and 2005 [14]. Greiber and Setzer [15] believed that expansionary monetary policy offers abundant liquidity and rises in housing prices.

The housing price rise synchronously with GDP and money supply in China until the year 2012, which well proved the fundamental role of GDP and money supply in determining the housing prices stated by the existing literature, what puzzling us however, is that when China's economy shifted gear and the currency release slowed down after 2012, housing prices still maintained high rate of growth, especially during the period 2015-2018 (see in Figure 1). As far as we know, no scholars have conducted research on this confusing phenomenon and given a reasonable explanation. There is no article covering whether there are different effects of shadow banking on China's real estate market among different periods either.

This paper aims to explain the mystery of the deviating house prices from the perspective of shadow banking money supply. Money supply among other macroeconomic factors is frequently proved to be the key influencing factor of housing prices around the world [12] [16], it is also one of the very important factors booming the Chinese real estate market. As confirmed by Wang et al. [17], a positive co-movement and causality between money supply growth and housing returns exist. However, the money supply considered by the general literature is the currency from the formal financial system and the shadow banking money from the informal financial system is ignored. In the aftermath of an unprecedented stimulus of multitrillion RMBs injected by the Chinese

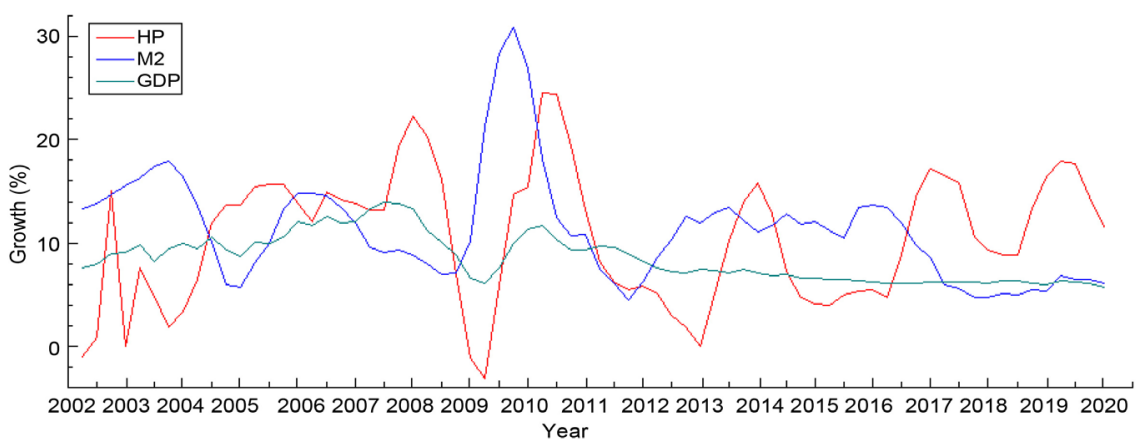

Figure 1. Quarter year-on-year growth of real GDP, M2 and Hp. 
government to combat the 2008 financial crisis, the People's Bank of China soon tighten the M2 supply between 2009 and 2015 to counteract the over flooded money generated by the previous stimulus plan [18]. Paradoxically, although the contractionary monetary policy had exerted an expected loan, it stimulated shadow banking and encouraged banks to bring shadow banking products onto their balance sheets in the form of risky non-loan assets. The share of shadow banking loans and bank loans increased steadily to around 20\% in 2013-2015 as estimated by [18].

The existing studies that focus on the nexus of money supply and housing prices in China have not addressed the role played by shadow banking which may be appropriate when the scale of the shadow banking money is small and negligible but leading to biased research conclusion when it reaches to a large size. The prevalence of credit supplied by non-bank financial institution via the shadow banking system had played an important role in the US and the UK after the financial crisis [19]. The Financial Stability Board [20] in China as well pointed out that non-bank credits contribute to financing the real economy. As far as we know, only Lai and Order [21] have formally tested the relationship between shadow banking and asset prices so far in China. Different from Lai and Order [21], however, our paper further explains the changes in the factors affecting China's housing prices pre- and after 2012 with shadow banking perspective.

To be specific, our paper contributes to the literature in several ways. First, as far as we know, we are the first to discover the above mentioned mystery that house prices in China deviated from the fundamental factors of GDP and money supply. Although we believe that the growth of house prices should slow down with GDP and money supply when the two fundamentals decelerated after the year 2012, the truth is contrary to what we expected which greatly provokes our interest; Second, we provide a reasonable explanation by taken shadow banking into consideration of the money supply. Despite the reduction of generalized money supply after the tightening monetary policy, the endogenous money supply which includes shadow banking currency did not decrease and flowed into the real estate market, by which we believe housing prices is supported; Finally, we do a serious of empirical experiments to prove the role play by shadow banking money in replacing economic growth and bank loan supply and get some inspiring results. 1) Before 2012, GDP and money supply were two important factors driving housing prices up in China, but the explanation for them became weaker after 2012. 2) In contrast, shadow banks' interpretation of house prices was weak before 2012 but gradually strengthened after then. 3) Shadow banking influences real estate market prices directly as well as through expanding the endogenous money supply.

\section{Empirical Methods and Data}

\subsection{Empirical Method}

Compare with the constant coefficient VAR model, the TVP-VAR model with 
time-varying parameters can describe two different forms of impulse response functions, which are equal-interval impulse response function and time-point impulse response function. Thus, this paper adopts the vector auto-regressive model with time-varying parameters and random fluctuations (TVP-VAR) proposed by Nakajima (2011), the TVP-VAR model can be written in the form as

$$
y_{t}=X_{t} \beta_{t}+A_{t}^{-1} \Sigma_{t} \varepsilon_{t}, \quad \varepsilon_{t} \sim N\left(0, I_{k}\right)
$$

where $t=s+1, \cdots, n, \quad y_{t}$ is a $(k \times 1)$ vector of observable variables; $X_{t}=I_{k} \otimes\left(y_{t-1}^{\prime}, \cdots, y_{t-s}^{\prime}\right), \otimes$ refers to the Kronecker product. The coefficients $\beta_{t}$, and the parameters $A_{t}^{-1}$ and $\Sigma_{t}$ are all time varying. Specifically, $A_{t}$ is a lower triangular matrix with a diagonal element of 1 and $\Sigma_{t}=\operatorname{diag}\left(\sigma_{1 t}, \cdots, \sigma_{k t}\right)$.

Following Primiceri (2005), We stack the lower left hand side of $A_{t}$ to get, $\alpha_{t}=\left(\alpha_{21}, \alpha_{31}, \cdots, \alpha_{k . k-1}\right)^{\prime}, \quad h_{t}=\left(h_{1 t}, \cdots, h_{k t}\right)^{\prime}, \quad h_{j t}=\log \sigma_{j t}^{2}, \quad j=1, \cdots, k$, $t=s+1, \cdots, n$. And the time varying parameter obeys the following random walk process:

$$
\begin{gathered}
\beta_{t+1}=\beta_{t}+u_{\beta t}, \quad \alpha_{t+1}=\alpha_{t}+u_{\alpha t}, \quad h_{t+1}=h_{t}+u_{h t} \\
\left(\begin{array}{l}
\varepsilon_{t} \\
u_{\beta t} \\
u_{\alpha t} \\
u_{h t}
\end{array}\right) \sim N\left(0\left(\begin{array}{cccc}
I & 0 & 0 & 0 \\
0 & \sum_{\beta} & 0 & 0 \\
0 & 0 & \sum_{\alpha} & 0 \\
0 & 0 & 0 & \sum_{h}
\end{array}\right)\right)
\end{gathered}
$$

where $t=s+1, \cdots, n, \quad \beta_{s+1} \sim N\left(u_{\beta 0}, \Sigma_{\beta 0}\right), \alpha_{s+1} \sim N\left(u_{\alpha 0}, \Sigma_{\alpha 0}\right)$, $h_{s+1} \sim N\left(u_{h 0}, \sum_{h 0}\right)$

In order to calculate the Bayesian posterior distribution needed for the model, we first estimate the time-varying parameters by the Monte Carlo Marcov Chain (MCMC) method.

\subsection{Variables and Data}

Among the many factors that affect housing prices, we first consider economic growth and money supply, for they are recognized as the most fundamental and most Chinese-specific factors affecting housing prices. Over the past few decades, China's economic growth has led the world, and domestic housing prices remain stubbornly high. Topics of housing prices and economic growth attract much attention, and the relationship between the two has been confirmed by a large number of literatures [6] [22] [23]. Similarly, the nexus of money supply and housing prices in China are also empirically proved by dozens of papers [24] [25]. As pointed out by Zhao [26], following a series of moderately loose monetary policies, China's money supply (M2) has grown fivefold in the past decade, leading to a persistent upward growth in housing prices. We agent economic growth by GDP per capita and denote it as gdp, besides, proxy money supply by endogenous money supply or generalized money supply which is denoted as $\mathrm{m} 2 \mathrm{e}$ or $\mathrm{m} 2$.

The impact of loans and interest rates on housing prices should not be neg- 
lected either, since the main way of purchasing commercial housing is residential mortgage loans. Many papers have analyzed the relationship between housing prices and mortgage loans, and find that easily available credit has been one of the common explanations for the housing boom, too [27] [28]. Interest rate is also reckoned as a house price determinant, and low interest rate substantially boosts housing demand and prices [29]. Thus, we include $r$ and loan referring to interest rate on loans of five or more years and the amount of credit loans respectively. Finally, discovered by Lai and Order [21], unprecedented growth in fixed asset investments were increasingly funded by shadow banking after the stimulus package initiated by the Chinese central government in response to the Global Financial Crisis, we therefore incorporate shadow banking loan in our research system denoted as sb and calculate as the sum of entrusted loans, trust loans and undiscounted bank acceptance.

In terms of housing prices, according to the mainstream practice of the existing researches, the average commercial housing prices calculated as the sales volume (yuan) divided by the sales area (square meters) are adopted and denoted as hp.

We estimate the TVP-VAR model using quarterly data from the first quarter of 2002 to the fourth quarter of 2019. Its noteworthy that we calculate money supply in another way instead of $\mathrm{m} 2$ by the rule introduced by Chen et al. [18] and get m2e to reflect the real endogenous supply of money. All the data come from China's national bureau of statistics and are seasonally adjusted and logarithmically differentiated. The empirical analysis of this paper is divided into three parts. To empirically study the impact of monetary policy on housing prices, we established System 1 denoted as $y_{1 t}=\left(g d p_{t}, m 2_{t}, r_{t}, l o a n_{t}, h p_{t}\right)^{\prime}$ in the first part. Next, in the second part, variable of shadow banking is included to further study its impact on housing prices where System 2 and System 3 expressed as $y_{2 t}=\left(g d p_{t}, m 2 e_{t}, r_{t}, \operatorname{loan}_{t}, h p_{t}\right)^{\prime}$ and $y_{3 t}=\left(g d p_{t}, s b_{t}, r_{t}, l o a n_{t}, h p_{t}\right)^{\prime}$ are introduced. Lastly, System 4 estimated as $y_{4 t}=\left(g d p_{t}, s b_{t}, m 2 e_{t}, r_{t}, l o a n_{t}, h p_{t}\right)^{\prime}$ in part 3 empirically analyzes the influence of shadow banking on monetary policy regulation of housing prices.

\section{Empirical Results}

The impulse response functions between variables are analyzed in this section. Since both the model parameters and structural shocks are time-varying, the impulse responses between the variables must also be time-varying. We firstly depict the impulse response graph of different lag phases in the entire sample period to catch the time-varying feature (diagram a), and then employ the lag phase impulse response in different periods to make comparison (diagram $b$ ).

We show the dynamic profiles of the housing prices when propagated a one-SD positive shock by other variables in the lag phase 1, 3 and 5 representing the short-, mid- and long-term respectively. Three observation points, namely, the first quarter of 2004, the first quarter of 2012 and first quarter of 2018 are chosen in diagram b. We select 2004, 2012 and 2018 as the cut off points based 
on the truth that the real estate market deviated from the economic growth ever since 2012, and the housing prices are rising faster, even as the Chinese government intensifies its efforts to crack down on property prices. These three time points also correspond to the periods when shadow banking began to develop, developed rapidly and developed steadily. An examination of these three periods is helpful in studying the time-varying feature at the reform time points as well as deeper learning the interacting mechanism of shadow banking, monetary policy and real estate market.

At first, System 1 denoted as $y_{1 t}=\left(g d p_{t}, m 2_{t}, r_{t}, l o a n_{t}, h p_{t}\right)^{\prime}$ is introduced to analyzed how economic growth and monetary policy affect housing prices and the results are displayed in Figures 2-5.

Firstly, as showed in Figure 2(a), the impulse responses of per capita GDP on housing prices are positive in the lag phase 1, 3 and 5. In Figure 2(b), the impulse responses of per capita GDP to housing prices at different time periods also present positive changes. The response of housing prices to GDP per capita was initially strong, but began to weaken in 2012 and was even weaker in 2016.
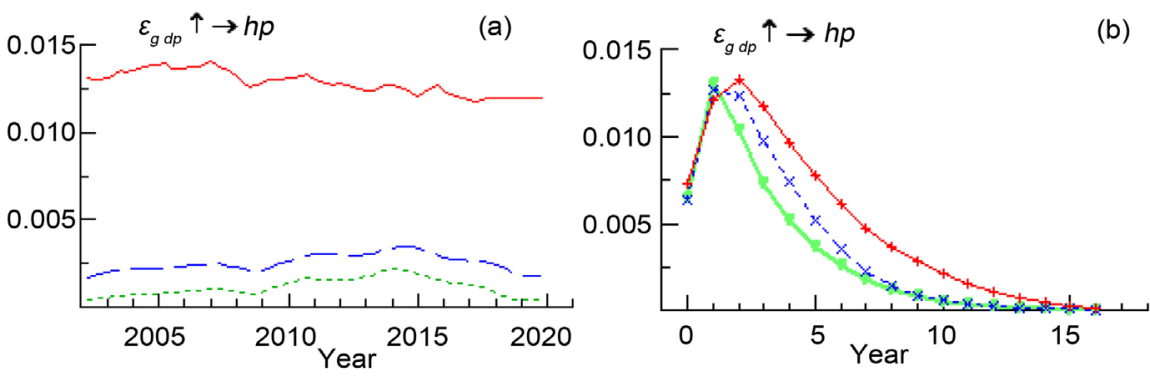

Figure 2. Impact of per capita GDP on housing prices ((a), (b)).
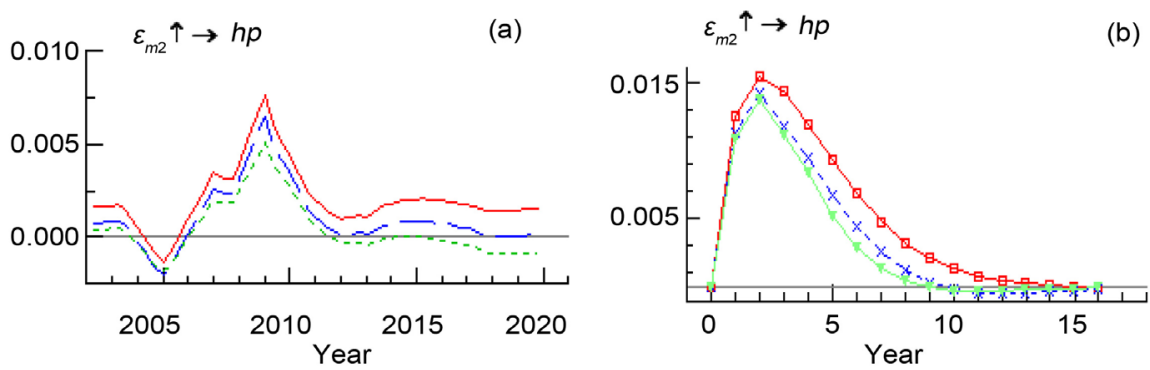

Figure 3. Influence of broad money supply on housing price ((a), (b)).
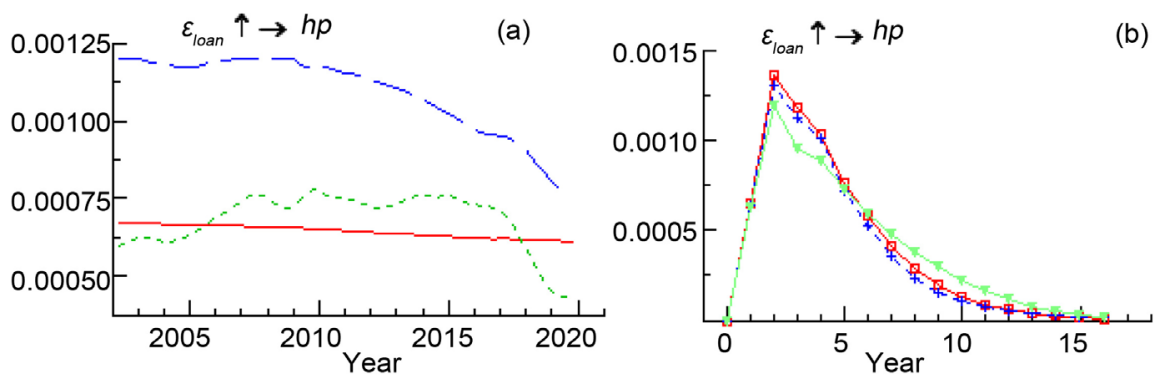

Figure 4. Influence of bank credit on housing prices ((a), (b)). 

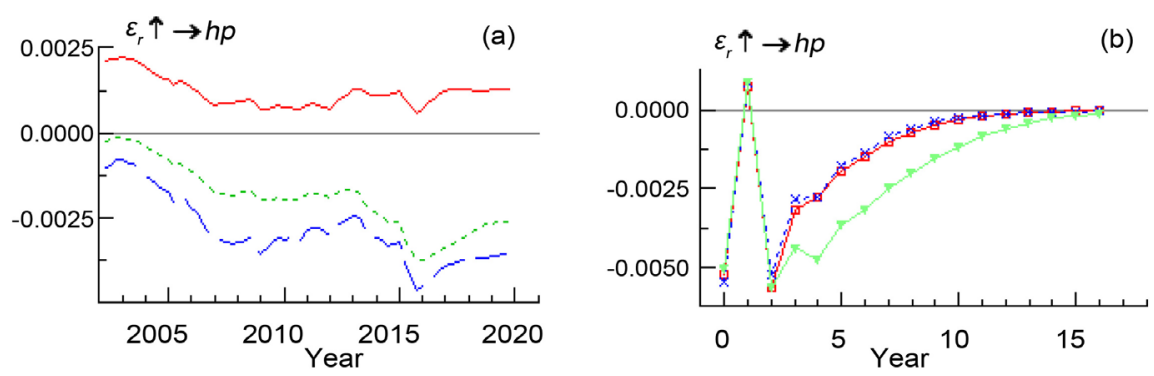

Figure 5. Influence of interest rate on housing price ((a), (b)).

This results indicate that GDP per capita has been one of the major momentum behind the fast rising housing prices in China in the past decade, in recent years however, with the transformation of economic and the deceleration in the economic growth, per capita GDP is playing a weaker and weaker role in promoting housing prices.

Similar to GDP, the impulse of money supply on housing prices also show time-varying features (See in Figure 3(a)). In line with the 4 trillion yuan bailout plan implemented by the People's Bank of China in response to the financial crisis in 2008, the influence of money supply on housing prices has kept rising from 2005 to 2009 and peaked in 2009. But the loose monetary policy turned to tight soon after $\mathrm{m} 2$ reached its peak. As a result, the promotion of $\mathrm{m} 2$ to housing prices has weaken since 2010 and even turned negative after 2012. The impulse responses in the time periods figure (Figure $3(\mathrm{~b})$ ) also confirm the above conclusion with a significantly greater positive response to house prices in the first quarter of 2004 than in the first quarter of 2012 and 2018. Likewise, the positive impact of bank credit on housing prices has also gradually waning and turned negative after 2015 (See in Figure 4(a) and Figure 4(b)). Finally, as can be seen from Figure 5, the response of housing prices to interest rates is positive and time lagged, therefore, raising interest rates will not bring house prices under control quickly in the short term.

The above results suggest that economic development and money supply are the primary impetus of prosperity in Chinese real estate market. What surprising is that, house price increased independently even when economic growth decelerated as well as money supply tightened after 2012 and especially after 2016. In explanation of this paradox, we further incorporate System 2 $y_{2 t}=\left(g d p_{t}, m 2 e_{t}, r_{t}, l o a n_{t}, h p_{t}\right)^{\prime}$ into our analysis, in which, the endogenous money supply estimated by Chen et al. (2018) is used to replace the generalized money supply. The resulting impulse response diagrams are shown in the following (Figure 6).

See from Figure 6(a), the impacts of the endogenous money supply on housing prices increased gradually in the lag phase 1, 3 and 5. The hysteresis responses of the three chosen time periods react basically the same too, reaching the peak in the second lag period and gradually converging to steady. The impulse response effect in the first quarter of 2018 is greater than that in the first quarter of 2004, indicating a great role play by endogenous money supply in pushing up 
(a)

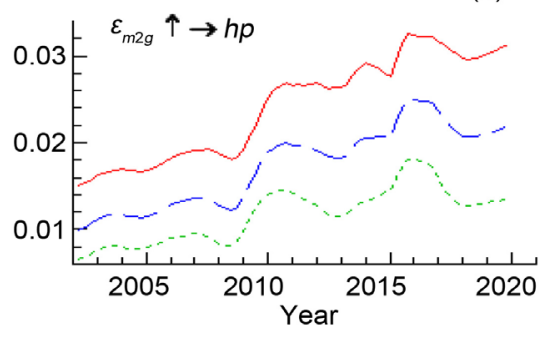

$\varepsilon_{m 2 g} \uparrow \rightarrow h p$

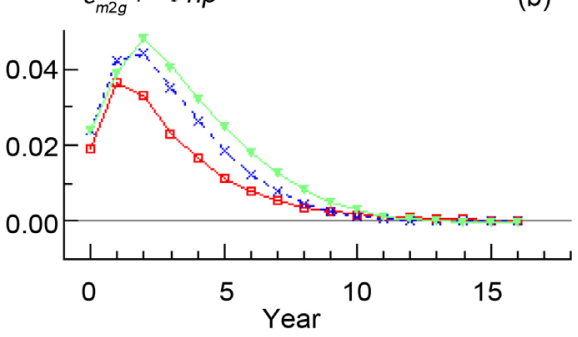

Figure 6. Influence of endogenous money supply on housing price ((a), (b)).

Chinese housing prices after the year 2012. As the endogenous money supply different from the generalized money supply in it contains shadow banking currency, we further introduce System $3 y_{3 t}=\left(g d p_{t}, s b_{t}, r_{t}, \text { loan }_{t}, h p_{t}\right)^{\prime}$ below to make a more in-depth analysis of shadow banking.

As shown in Figure 7(a), when a one-SD shock is propagated by the shadow banking money supply, the housing prices react positively in the lag phase 1, 3 and 5 and the effect is increasing over time. In Figure 7(b), the influences of shadow banking on real estate prices in the three different time periods are basically the same, exempt that the positive impact in the first quarter of 2018 is greater than that in the first quarter of 2012 and the first quarter of 2004. This shows that although the tight monetary policy has reduced bank credit and broad money supply, as a supplement to traditional credit, shadow banking has not decreased, and most of the shadow banking funds have flowed to the real estate market, thus promoting the prosperity of the real estate market, and even assuming the supporting role of economic growth and money supply for real estate. After 2012, shadow banking is an important reason for the rise of housing prices in China.

Finally, on the basis of the above analysis, this paper comprehensively considers the influence of both the shadow banking currency and the monetary polices by introducing System 4 as $y_{4 t}=\left(g d p_{t}, s b_{t}, m 2 e_{t}, r_{t}, \operatorname{loan}_{t}, h p_{t}\right)^{\prime}$.

According to Figure 8(a), the impulse response of endogenous money supply (m2e) to shadow banking (sb) is basically positive, which is to say, the endogenous money supply increases with the expansion of shadow banking. While showed by Figure $8(\mathrm{~b})$, the influence of shadow banking on endogenous money supply was positive at all three time points, peaked around the first period, leveled off around the eighth period, and had the largest positive impact in the first quarter of 2018. In conclusion, shadow banking has a positive amplify effect on money supply, that's why the promoting effect of the generalized money supply which excludes shadow banking money is weakening, while on the opposite, the effect of the endogenous money supply which includes shadow banking money is gradually enhancing.

In Figure 9(a), the responses of interest rate(r) in lag phase 1, 3 and 5 to shadow banking are all positive, which is to say shadow banking pushes up the interest rate. And this effect keeps increasing before the year 2012 but decreasing 

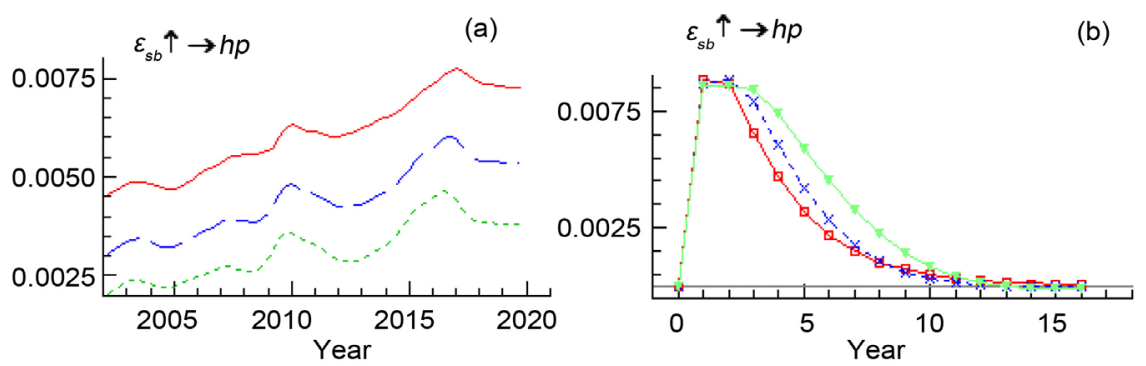

Figure 7. Impact of shadow banking on housing prices ((a), (b)).
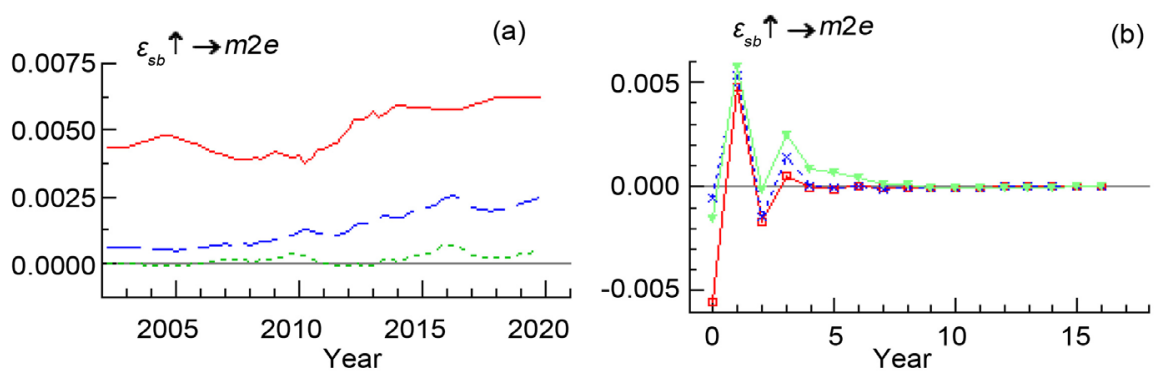

Figure 8. Impact of shadow banking on endogenous money supply ((a), (b)).
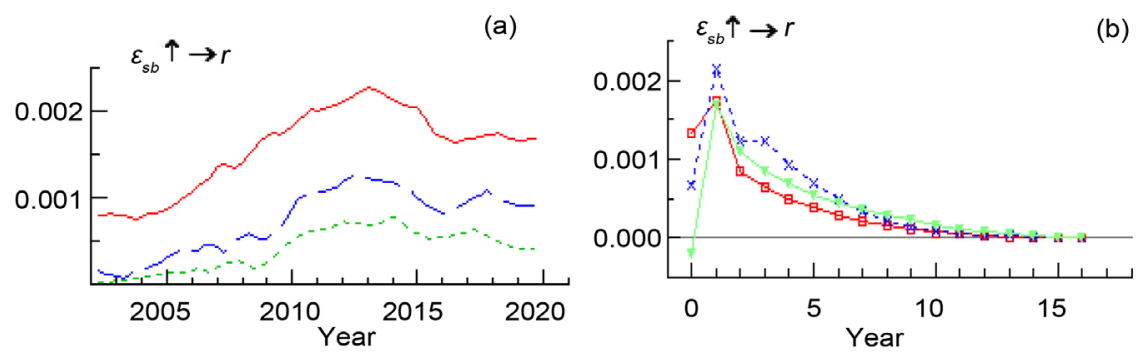

Figure 9. Impact of shadow banking on interest rates ((a), (b)).
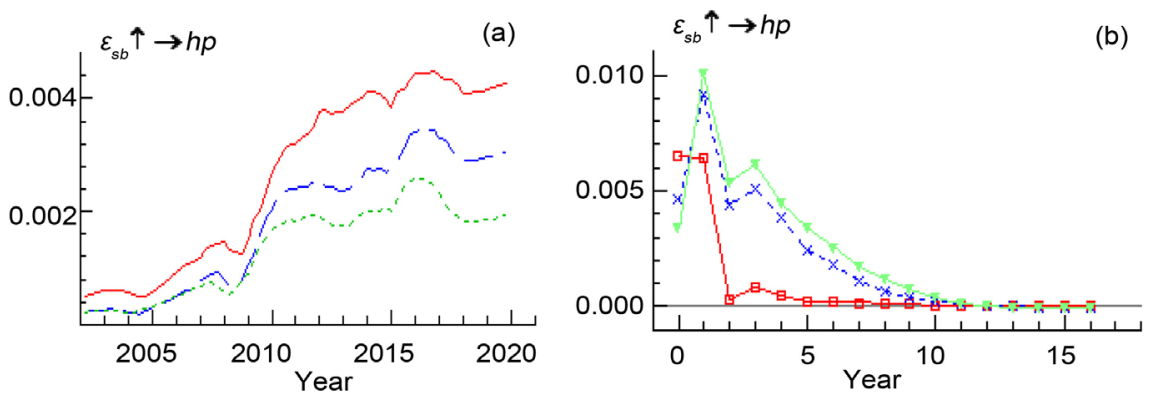

Figure 10. Impact of shadow banking on house prices ((a), (b)).

there after. Similar conclusion is drawn from Figure $9(\mathrm{~b})$ that the positive response of interest rate to shadow banking shocks in 2012 is greater than that in 2004. The high-risk and high-yield nature of shadow banking makes its interest rate much higher than that in the formal banks', thereby, pushes up the market interest rate and then affects the effectiveness of monetary policy.

The impulse response analysis is later applied to estimate the effects of shadow banking and endogenous money supply on housing prices. The diagrams 

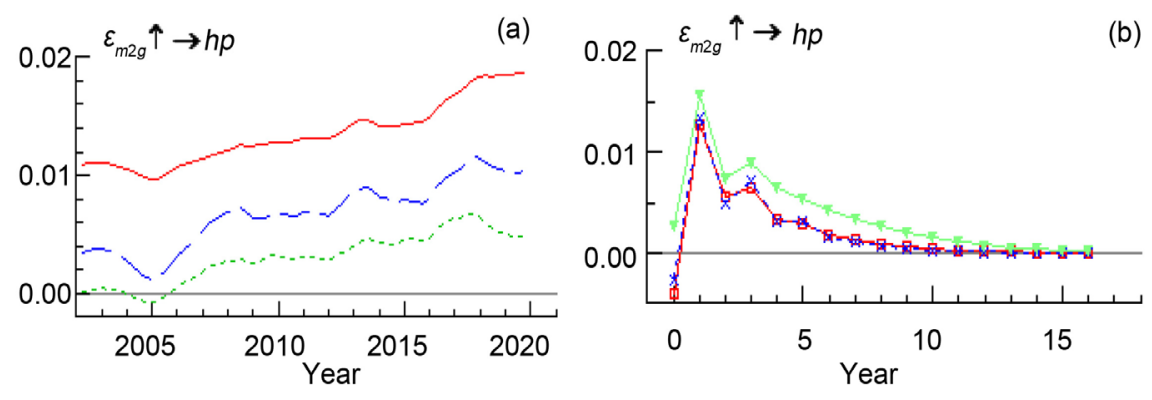

Figure 11. Impact of endogenous money supply on house prices ((a), (b)).

showed in Figure 10(a) and Figure 11(a) demonstrate that the responses of housing prices to shadow banking and endogenous money supply are positive in the lag phase 1, 3 and 5. In addition, the impulse responses in different time periods (see in Figure 10(b) and Figure 11(b)) are also positive and gradually strengthened along time. These again, not only confirm the finding in the above but also the robustness of our results.

\section{Conclusion}

When GDP and the money supply (M2), the two key demand fundamentals of China's housing prices, shifted gears and decelerated after 2012, the housing prices maintained high growth rates, specifically in the period of 2015-2018. To address these puzzling phenomena, we explicitly examine the factors affecting housing prices and make comparisons between the per- and after 2012 periods by using the TVP-VAR model. We do empirical analysis in different lag phases and different time periods, specifically, we consider the effects of different levels of money supply on housing prices, including the generalized money supply and the endogenous money supply with or without shadow banking currency. The empirical results show that before 2012, macro-fundamental factors such as money supply and per capita GDP are the key factors driving the rise of housing prices. But after 2012, shadow banking became a key driver instead of money supply and per capita GDP. These results suggest that there may be a bubble in the Chinese housing prices after 2012. In order to stabilize the housing prices, the Chinese government should closely monitor shadow banking in preventing the flow of shadow bank loans from entering the real estate market.

\section{Acknowledgements}

Tan is grateful for the Hunan Provincial Innovation Foundation for Postgraduate (No. CX20200492). Li appreciates for the research fund granted by Department of Education of Guangdong Province (No. 2018WQNCX136).

\section{Conflicts of Interest}

The authors declare no conflicts of interest regarding the publication of this paper. 


\section{References}

[1] Chow, G.C. and Niu, L. (2010) Demand and Supply for Residential Housing in Urban China. Journal of Financial Research, 44, 1-11.

[2] Deng, Y., Gyourko, J. and Wu, J. (2012) Land and House Price Measurement in China. National Bureau of Economic Research, Cambridge. https://doi.org/10.3386/w18403

[3] Zhu, H., Li, Z. and Guo, P. (2018) The Impact of Income, Economic Openness and Interest Rates on Housing Prices in China: Evidence from Dynamic Panel Quantile Regression. Applied Economics, 50, 4086-4098. https://doi.org/10.1080/00036846.2018.1441512

[4] Glaeser, E.L. and Nathanson, C.G. (2017) An Extrapolative Model of House Price Dynamics. Journal of Financial Economics, 126, 147-170. https://doi.org/10.1016/j.jfineco.2017.06.012

[5] Tan, Z.X., Liu, J. and Chen, P. (2021) The Trend and Cycle Components of China's Housing Prices: A New Decomposition Method. Applied Economics. https://doi.org/10.1080/00036846.2021.1877254

[6] Li, J. and Chiang, Y.H. (2012) What Pushes Up China's Real Estate Price? International Journal of Housing Markets and Analysis, 5, 3-22. https://doi.org/10.1108/17538271211225913

[7] Oikarinen, E., Bourassa, S.C., Hoesli, M., et al. (2018) US Metropolitan House Price Dynamics. Journal of Urban Economics, 105, 54-69. https://doi.org/10.1016/j.jue.2018.03.001

[8] Aizenman, J., Jinjarak, Y. and Zheng, H. (2016) House Valuations and Economic Growth: Some International Evidence. National Bureau of Economic Research, Cambridge, No. w22699. https://doi.org/10.3386/w22699

[9] Yang, Z., Wang, S. and Campbell, R. (2010) Monetary Policy and Regional Price Boom in Sweden. Journal of Policy Modeling, 32, 865-879.

https://doi.org/10.1016/j.jpolmod.2010.06.004

[10] Lastrapes, W.D. (2002) The Real Price of Housing and Money Supply Shocks: Time Series Evidence and Theoretical Simulations. Journal of Housing Economics, 1, 40-74. https://doi.org/10.1006/jhec.2002.0309

[11] Gupta, R., Jurgilas, M. and Kabundi, A. (2010) The Effect of Monetary Policy on Real House Price Growth in South Africa: A Factor-Augmented Vector Autoregression (FAVAR) Approach. Economic Modelling, 27, 315-323.

https://doi.org/10.1016/j.econmod.2009.09.011

[12] Kondybayeva, S.K. and Ishuov, Z.S. (2013) The Effect of Monetary Policy on Real House Price Growth in the Republic of Kazakhstan: A Vector Autoregression Analysis. World Applied Sciences Journal, 22, 1384-1394.

[13] Ahearne, A.G., Ammer, J., Doyle, B.M., et al. (2005) Monetary Policy and Housing Prices: A Cross-Country Study. FRB International Finance Discussion Paper 841. https://doi.org/10.2139/ssrn.816946

[14] Wheaton, W. and Nechayev, G. (2008) The 1998-2005 Housing "Bubble" and the Current "Correction": What's Different This Time? Journal of Real Estate Research, 30, 1-26. https://doi.org/10.1080/10835547.2008.12091212

[15] Greiber, C. and Setzer, R. (2007) Money and Housing: Evidence for the Euro Area and the US.

[16] McCarthy, J. and Peach, R.W. (2002) Monetary Policy Transmission to Residential 
Investment. FRBNY Economic Policy Review, 8, 139-158.

[17] Wang, X.Q., Hao, L.N., Tao, R., et al. (2020) Does Money Supply Growth Drive Housing Boom in China? A Wavelet-Based Analysis. Journal of Housing and the Built Environment, 35, 125-141. https://doi.org/10.1007/s10901-019-09668-w

[18] Chen, K., Ren, J. and Zha, T. (2018) The Nexus of Monetary Policy and Shadow Banking in China. American Economic Review, 108, 3891-3936.

https://doi.org/10.1257/aer.20170133

[19] Bordo, M.D. and Landon-Lane, J. (2013) Does Expansionary Monetary Policy Cause Asset Price Booms; Some Historical and Empirical Evidence (No. w19585). National Bureau of Economic Research, Cambridge. https://doi.org/10.3386/w19585

[20] Financial Stability Board (2015) Global Shadow Banking Monitoring Report 2015 (November 2015).

[21] Lai, R.N. and Van Order, R. (2019) Shadow Banking and the Property Market in China. International Real Estate Review, 22, 361-399.

[22] Xu, T. (2017) The Relationship between Interest Rates, Income, GDP Growth and House Prices. Research in Economics and Management, 2, 30-37. https://doi.org/10.22158/rem.v2n1p30

[23] Yu, H. (2010) China's House Price: Affected by Economic Fundamentals or Real Estate Policy? Frontiers of Economics in China, 5, 25-51. https://doi.org/10.1007/s11459-010-0002-7

[24] Lin, X.H. (2014) The Relationship between Incremental Change of M2 and Real Estate Price Volatility: Theory and Empirical Analysis. Working Paper, East China Normal University, Shanghai.

[25] Shi, W. (2016) An Empirical Study of the Interaction between Money Supply and Asset Price Based on Granger Causality Test in Frequency Domain. Journal of Hefei University of Technology (Social Sciences), 4, 25-31.

[26] Zhao, G.L. (2015) Endogenous Research and Empirical Test on Chinese Money Supply. Review of Economy and Management, 5, 133-139.

[27] Hofmann, B. (2003) Bank Lending and Property Prices: Some International Evidence. https://doi.org/10.2139/ssrn.1009079

[28] Fitzpatrick, T. and McQuinn, K. (2004) House Prices and Mortgage Credit: Empirical Evidence for Ireland. Research Technical Paper 5. Bank of Ireland.

[29] Mayer, C. and Sinai, T. (2009) US House Price Dynamics and Behavioral Finance. Policy Making Insights from Behavioral Economics. Federal Reserve Bank of Boston, Boston. 